\title{
Foliar sources of boron and manganese in soybean and zinc plants in corn plants complexed with polyols in nutritional status and in production
}

\author{
Fuentes foliares de boro y manganeso en plantas \\ de soya y fuentes de zinc en plantas de maíz suplementadas con \\ polioles en estado nutricional y en producción del cultivo \\ André Mendes Coutinho Neto', Gilmara Pereira da Silva², \\ Edson Luiz Mendes Coutinho ${ }^{1}$, Renato de Mello Prado ${ }^{1}$
}

\begin{abstract}
Alternative sources of micronutrients have appeared on the market from B, Mn, and $\mathrm{Zn}$ complexes with polyols without scientific evidence on their agronomic effects compared to conventional sources, which is a concern when high fertilizer efficiency is sought Leaf. This study's objective was to evaluate the levels of $\mathrm{Mn}, \mathrm{B}$, and $\mathrm{Zn}$ leaf and grain and grain yield as a function of foliar application of doses and sources of Mn and B in soybean and Zn maize. They studied different sources of Mn (manganese sulphate, Mn-EDTA chelate, and Mn complex with lignosulfonate and with polyol), B (boric acid, B complex with polyol) in soybean and $\mathrm{Zn}$ (zinc sulfate, Zn-EDTA and Zn complex with polyol). Foliar application of sources and doses of Mn and B in the soybean and $\mathrm{Zn}$ crops in the maize crop does not influence plant nutrition and grain production. Foliar application of soluble sources, chelates, and alternative sources of $\mathrm{Mn}, \mathrm{B}$ in the soybean, and $\mathrm{Zn}$ crops in maize crops present similar agronomic efficiencies in plant nutrition and grain production.
\end{abstract}

Keywords: Glycine max, Zea mays, micronutrients and foliar fertilization.

\section{RESUMEN}

Existe fuentes alternativas de micronutrientes han aparecido en el mercado de los complejos de B, Mn y Zn con polioles, respecto a fuentes convencionales, lo cual es una preocupación cuando se busca una alta eficiencia de la fertilización. El objetivo de este estudio fue evaluar los niveles de Mn, B y Zn en hojas y granos, conjuntamente con el rendimiento de granos en función de la aplicación foliar de dosis y fuentes de Mn y B en soja y Zn en maíz. Se estudiaron diferentes fuentes de Mn (sulfato de manganeso, quelato de Mn-EDTA y complejo de Mn con lignosulfonato y con poliol), B (ácido bórico, complejo B con poliol) en soja y Zn (sulfato de zinc, Zn-EDTA y complejo de Zn con poliol) La aplicación foliar de fuentes y dosis de Mn y B en los cultivos de soja y Zn en el cultivo de maíz no influye en la nutrición de las plantas y la producción de granos. La aplicación foliar de fuentes solubles, quelatos y fuentes alternativas de $\mathrm{Mn}$, B en los cultivos de soja y Zn en cultivos de maíz presentan eficiencias agronómicas similares en la nutrición de las plantas y la producción de granos.

Palabras clave: Glycine max, Zea mays, micronutrientes y fertilización foliar.

\section{Introduction}

Foliar fertilization is an important agricultural practice for sustainable management and an increase in production of annual crops such as soybean and corn (Fernández et al., 2013). It is used to correct nutritional deficiencies, especially of micronutrients such as manganese (Mn), boron (B), and zinc (Zn) (Fernández and Brown, 2013), especially when the availability of micronutrients in the soil is low.

There are several sources of micronutrients in this scenario, especially soluble salts and chelates, particularly EDTA, in addition to alternative

1 Department of Soils and Fertilizer; Universidade Estadual Paulista Júlio de Mesquita Filho. Jaboticabal, SP, Brasil.

2 State University of Mato Grosso - UNEMAT, University Campus of Alta Floresta. Alta Floresta - MT, Brazil.

* Corresponding Author: gilmaraagronoma@gmail.com https://orcid.org/0000-0002-2996-6074 
sources. Mineral salts such as sulfate have high solubility, availability and low cost compared to other sources of micronutrients. The chelated sources are also soluble in water, but, results in less cuticular penetration and adjacent tissues due to the molecules' size. However, after being absorbed, its translocation in the plant is faster (Camargo, 1990).

Despite the differences between the salts and chelates, studies show that these can present similar agronomic efficiencies in different cultures' growth and production (McBeath and McLaughlin 2014; Shivay et al., 2016).

Specifically, in the soybean crop where $\mathrm{Mn}$ deficiency is common, it has been reported that the foliar application of this nutrient in salt form $\left(\mathrm{MnSO}_{4}\right)$ was as effective as the application of the chelate source (Mn-EDTA) in the production of this crop.

$\mathrm{Zn}$ is another micronutrient that deserves attention regarding its application via foliar, mainly in corn, cereal susceptible to this nutrient's deficiency. Therefore, the foliar application of zinc in the sulfate form in this crop promotes an increase in production (Imran and Rehim, 2017), together with an increase in the grain's micronutrient concentration (Wang et al., 2012). Even increasing the $\mathrm{Zn}$ content in the grain induces biofortification benefiting human health given the limited access of the micronutrient in the diet.

Additionally, $\mathrm{Zn}$ deficiency is also reported to be a B deficiency, especially in pulses such as soybeans, which causes significant losses in crop production due to the restriction on reproductive development (Chatterjee et al., 2014). Borone is the main source of B via leaf foliage used to correct nutritional deficiencies, with beneficial effects on production (Singh et al., 2013), and others did not interfere with production (Calonego et al., 2010).

An alternative to increase the efficiency of foliar fertilization with boron in soybean would be using an alternative source of the nutrient from element complex with polyols, such as sorbitol, with a possible increase of nutrient mobility increasing the residual effect of foliar nutrition. However, there are doubts about this alternative source could be efficient in improving the mobility of $\mathrm{B}$, reflecting the production of grains, as there are reports of no effect of this polyol via foliar in the redistribution of B (Will et al., 2012). A recent study in another legume the Vigna unguiculate, showed that foliar fertilization with $\mathrm{B}$, associated with sorbitol application was not viable (Silva et al., 2018).

The low stability of the polyol-complexed fertilizer inside the plant with B can occur with $\mathrm{Zn}$ and $\mathrm{Mn}$, which may limit the potential of this source in foliar fertilization.

In view of this, alternative sources of micronutrients have appeared on the market from $\mathrm{B}, \mathrm{Mn}$, and $\mathrm{Zn}$ complexes with polyols, however, it is necessary to evaluate the agronomic efficiency of these sources compared to conventional sources in foliar fertilization.

Thus, it is hypothesized that the foliar application of soluble sources, chelates, and the alternative with $\mathrm{Mn}$ and B polyols in the soybean and $\mathrm{Zn}$ crops in the maize crop will present similar agronomic efficiencies in plant nutrition and grain production. Thus, the present work aimed to evaluate the growth, the concentration of leaf $\mathrm{Mn}, \mathrm{B}$ and $\mathrm{Zn}$, and grain yield in response to foliar application of sources and doses of Mn and B in soybean and $\mathrm{Zn}$ culture in the crop of corn.

\section{Material and methods}

The experiment was carried out at the Faculty of Agrarian and Veterinary Sciences - Campus of Jaboticabal-SP, Brazil, from three experiments, being the experiment I developed in a greenhouse with soybean plants, cultivar AS 3730 IPRO and experiment II and III, Developed in the field, with soybean cultivars AS 3730 IPRO, and maize plants, hybrid AS 1633 PRO2, respectively.

\section{Experiment I}

The samples were collected from a typical clayey soil $($ clay $=79 \%$, silte $=10 \%$, sand $=11 \%$ ) and were collected in the superficial layer of 0 $0.2 \mathrm{~m}$ depth, In the municipality of Sacramento - MG, in an area where soybean has presented Mn deficiency problems.

The samples of soils after drying in the air were dewormed and sieved with a $6 \mathrm{~mm}$ mesh opening and afterwards the chemical analysis was performed for soil fertility purposes, yielding the following results: $\mathrm{pH}$ (in $\mathrm{CaCl}_{2}$ ) $=5.6$; M.O. $=28 \mathrm{~g}$ $\mathrm{dm}^{-3} ; \mathrm{P}($ resin $)=22 \mathrm{mg} \mathrm{dm}^{-3} ; \mathrm{K}=2.2 \mathrm{mmol}$ $\mathrm{dm}^{-3} ; \mathrm{Ca}=63 \mathrm{mmol} \mathrm{\textrm {dm } ^ { - 3 }} ; \mathrm{Mg}=21 \mathrm{mmol}$ $\mathrm{dm}^{-3} ; \mathrm{H}+\mathrm{Al}=31 \mathrm{mmol} \mathrm{dm}^{-3} ; \mathrm{SB}$ (Sum of 
bases) $=86.12 \mathrm{mmolc} \mathrm{dm}^{-3}$; CTC (cation exchange capacity) $=117.2 \mathrm{mmol} \mathrm{dm}^{-3}$ and $\mathrm{V}$ (base saturation index $)=74 \%$. The content of $\mathrm{Mn}=0.9 \mathrm{mg} \mathrm{dm}^{-3}$ was also determined.

The experiment was conducted in a completely randomized experimental design, with three replications, in a 4 × 3 factorial scheme, four sources, and three doses of Mn. Each experimental unit consisted of a vessel with $2.8 \mathrm{~kg}$ of soil, totaling 36 vessels.

$\mathrm{Mn}\left(\mathrm{MnSO}_{4}-31 \% \mathrm{Mn}\right)$ complexed with EDTA (Mn-EDTA - 13\% Mn), Mn complexed with lignosulfonate (Mn-LS - 7\% Mn, d = 1, 25) and Mn complexed with polyol [Mn-Polyol - 4.36\% $\left.\operatorname{Mn}\left(51.0 \mathrm{~g} \mathrm{~L}^{-1}\right)\right]$.

The doses of $\mathrm{Mn}\left(0 ; 175\right.$ and $\left.350 \mathrm{~g} \mathrm{ha}^{-1}\right)$, which correspond to the absence of $\mathrm{Mn}$, were employed; $50 \%$ of the recommended dose for the soybean crop and $100 \%$ of the recommended Mn dose for the soybean crop, respectively.

All treatments received fertilization with $200 \mathrm{mg} \mathrm{kg}^{-1}$ of $\mathrm{P}$ (monobasic calcium phosphate p.a.); $\left(\mathrm{Kg}^{-1}\right)$ of $\mathrm{K}$ and $49 \mathrm{mg} \mathrm{kg}^{-1}$ of $\mathrm{S}$ (potassium sulphate pa), $200 \mathrm{mg} \mathrm{kg}^{-1}$ of $\mathrm{N}$ (ammonium nitrate pa), $0.5 \mathrm{mg} \mathrm{kg}^{-1}$ of B (boric acid pa); $0.1 \mathrm{mg} \mathrm{kg}^{-1} \mathrm{Mo}$ (ammonium molybdate p.a.) and $1.5 \mathrm{mg} \mathrm{kg}^{-1} \mathrm{Zn}$ (zinc sulfate p.a.). Nitrogen fertilization was divided by application of $1 / 3$ of the dose at sowing and the rest in cover, 10 days after the emergence of the plants. After seven days of the plants' emergence, thinning was done, leaving three plants per pot.

Foliar fertilization of Mn was performed in only one application at 14 days after emergence of the plants when they were in the vegetative stage V2. The soil surface of each vase was protected with cardboard during the foliar application of the products.

Daily watering with distilled water was carried out during the experimental period, employing weighing the pots, maintaining soil moisture at $80 \%$ of its maximum water retention capacity.

The plants were cut close to the soil at 31 days after emergence. The plants were then washed with distilled water, diluted detergent solution, and 0.1 mol L ${ }^{-1} \mathrm{HCl}$ solution and subsequently dried In a forced ventilation oven at $65^{\circ} \mathrm{C}$ for 72 hours, the time required for the material to reach the constant weight and then weighed for the determination of dry matter yield.

Afterward, the plant's leaf was ground in a Willey mill and the analysis of the Mn content.
The data were submitted to analyze the variance, using the $\mathrm{F}$ test at $5 \%$ of probability. When significant to sources and doses of B were compared by the Tukey test at the 5\% probability level. The analyzes were carried out using the statistical program AgroEstat.

\section{Experiment II}

A field experiment was carried out with soybean cultivation on a clayey dystrophic Red Latosol. Before the installation of the experiment, soil chemical analysis was carried out for fertility purposes in the $0-0.20 \mathrm{~m}$ depth layer, yielding the following results: $\mathrm{pH}$ (in $\mathrm{CaCl}_{2}$ ) $=5.5 ;$ M.O. $=21 \mathrm{~g} \mathrm{dm}^{-3} ; \mathrm{P}($ resin $)=22 \mathrm{mg}$ $\mathrm{dm}^{-3} ; \mathrm{K}=2.4 \mathrm{mmol} \mathrm{dm}^{-3} ; \mathrm{Ca}=28 \mathrm{mmol}, \mathrm{dm}^{-3}$; $\mathrm{Mg}=18 \mathrm{mmol} \mathrm{dm}^{-3} ; \mathrm{H}+\mathrm{Al}=31 \mathrm{mmol} \mathrm{dm}^{-3} ; \mathrm{SB}$ (Sum of bases) $=48.40 \mathrm{mmol} \mathrm{dm}^{-3}$; CTC (cation exchange capacity) $=79.4$ mmolc $\mathrm{dm}^{-3} ; \mathrm{V}$ (base saturation index) $=71 \%$ and $\mathrm{B}=0.15 \mathrm{mg} \mathrm{dm}^{-3}$.

The climatic data regarding the average maximum and minimum air temperatures and rainfall during the experimental period were adequate, with no water limitations, totaling 1211 $\mathrm{mm}$ during the experimental period (Figure 1).

The experiment was conducted in a randomized block design, in a $4 \times 2$ factorial scheme with four doses and two B sources, with three replicates.

The doses of B used were $(0 ; 450 ; 900$; $1,350 \mathrm{~g} \mathrm{ha}^{-1}$ ) corresponding to the control (without foliar fertilization with B); An application of $450 \mathrm{~g} \mathrm{ha}^{-1}$ in the V4 stage; Two applications of $450 \mathrm{~g} \mathrm{ha}^{-1}$ in the V4 and V7 stages and three applications of $450 \mathrm{~g} \mathrm{ha}^{-1}$ in the V4, V7 and R2 stages, respectively. The dose of $450 \mathrm{~g} \mathrm{ha}^{-1}$ of B via foliar was used as standard.

The sources of B, applied by foliar route, were boric acid and boric acid complexed with polyol - B - Polyol.

The applications were carried out with a sprayer, with a spray volume of $120 \mathrm{~L} \mathrm{ha}^{-1}$. The adjacent plots were protected with plastic sheeting to avoid contamination.

Seeding was performed using soybeans previously inoculated with Bradyrhizobium ( $250 \mathrm{~g}$ of inoculant per $50 \mathrm{~kg}$ of seeds). All plots received sowing fertilization with $60 \mathrm{~kg} \mathrm{ha}^{-1}$ of $\mathrm{P}_{2} \mathrm{O}_{5}$ and $60 \mathrm{~kg} \mathrm{ha}^{-1}$ of $\mathrm{K}_{2} \mathrm{O}$.

The plots consisted of six lines of $5 \mathrm{~m}$ in length, spaced $0.45 \mathrm{~m}$, corresponding to a total area of $13.5 \mathrm{~m}^{2}$, and a useful area of $9.0 \mathrm{~m}^{2}$. 


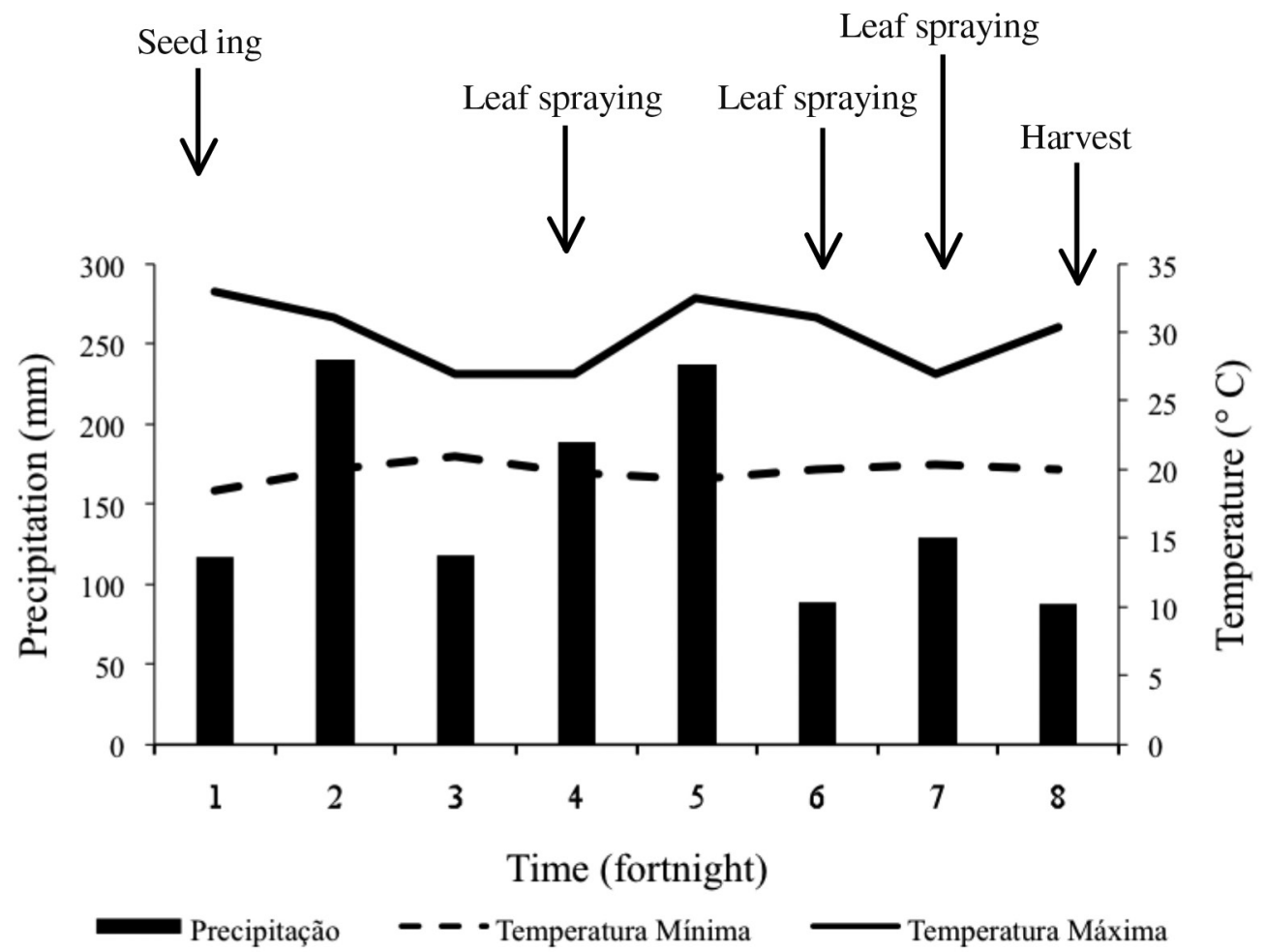

Figure 1. Bi-weekly mean values of maximum, minimum air temperatures, and rainfall during the experimental period. Source: FCAV/Unesp Agroclimatological Station, 2016. 1: $2^{\text {nd }}$ fortnight of November 2015; 2 and 3: December 2015; 4 and 5: January 2016; 6 and 7: February 2016; 8: the $1^{\text {st }}$ fortnight of March 2016.

To assess the plants' nutritional status, 25 plants were harvested at random in each plot's useful area, the third leaf with a petiole from the main stem's apex. The plant material was taken to the laboratory, washed with distilled water, diluted detergent solution, and $0.1 \mathrm{~mol} \mathrm{~L}^{-1} \mathrm{HCl}$ solution.

The plant material was then placed to dry in a forced ventilation oven at $65^{\circ} \mathrm{C}$ for 72 hours, the time required for the material to reach constant weight. Subsequently, the plant material was ground in a Willey mill, and the B content was determined.

The evaluation of grain yield was performed, harvesting the plants of the useful area of each plot, which were weighed, and the grain yield was expressed with $13 \%$ moisture. Also, a grain sample was separated from each plot to analyze the B content.

The data were submitted to analyze the variance, using the $\mathrm{F}$ test at $5 \%$ of probability. When significant to the B sources, they were compared by the Tukey test at the $5 \%$ probability level, and for the B doses, the polynomial regression analysis was performed. The analyzes were carried out using the statistical program AgroEstat.

\section{Experiment III}

The experiment was carried out in the field in medium-dystrophic Red Latosol. The area was cultivated in the no-tillage system, with maize growing during the summer and remaining fallow during the winter.

Before the installation of the experiment, a soil sample was collected from the experimental area in the superficial layer $0-0.20 \mathrm{~m}$ depth, and the chemical analysis was performed for fertility purposes, yielding the following results: $\mathrm{pH}$ (in $\left.\mathrm{CaCl}_{2}\right)=5.4 ;$ M.O. $=19 \mathrm{~g} \mathrm{dm}^{-3} ; \mathrm{P}($ resin $)=29 \mathrm{mg}$ $\mathrm{dm}^{-3} ; \mathrm{K}=1.5 \mathrm{mmol} \mathrm{dm}^{-3} ; \mathrm{Ca}=35 \mathrm{mmol} \mathrm{dm}^{-3}$; $\mathrm{Mg}=10 \mathrm{mmol} \mathrm{dm}^{-3} ; \mathrm{H}+\mathrm{Al}=22 \mathrm{mmol} \mathrm{dm}^{-3} ; \mathrm{SB}$ $($ Sum of bases $)=46.50 \mathrm{mmol} \mathrm{dm}^{-3} ;$ CTC $($ cation exchange capacity) $=68.5 \mathrm{mmolc} \mathrm{dm}^{-3} ; \mathrm{V}$ (base saturation index) $=68 \%$ and $\mathrm{Zn}=0.3 \mathrm{mg} \mathrm{dm}^{-3}$. 
The climatic data regarding the average maximum and minimum temperatures and rainfall during the experimental period were adequate, with no water limitations, totaling $912 \mathrm{~mm}$ (Figure 2).

A randomized complete block design with three replications was used in a $3 \times 3$ factorial scheme, with three sources and three $\mathrm{Zn}$ doses. The fertilizer sources used were $\mathrm{Zn}$ sulfate (reference source), Zn-EDTA (complexed with EDTA); Znpolyol (complexed with polyol). The doses of $\mathrm{Zn}$ used were $0 ; 1$ and $2 \mathrm{~g} \mathrm{~L}^{-1}$ corresponding to the absence of $\mathrm{Zn}$ application; 50\% and 100\% applied in the V5, V7 and V8 stages.

The plots consisted of six lines $5 \mathrm{~m}$ long, spaced $0.80 \mathrm{~m}$, corresponding to a total area of 24 $\mathrm{m} 2$ and a useful area of $16 \mathrm{~m}^{2}$. The experimental units were separated by $2 \mathrm{~m}$ carriers.

Leaf applications were performed with a costal spray, using an empty cone with a volume of 120 $\mathrm{L} \mathrm{ha}^{-1}$, while in the other sprays, $180 \mathrm{~L} \mathrm{ha}^{-1}$ of water was used. The adjacent parcels to which it was being sprayed were protected with plastic tarpaulin to avoid contamination.
The corn hybrid's sowing was carried out, aiming to obtain a final population of 60 thousand plants per hectare.

All plots received the same fertilization with $\mathrm{N}, \mathrm{P}$, and $\mathrm{K}$ at sowing $\left(30 \mathrm{~kg} \mathrm{ha}^{-1}\right.$ of N, $90 \mathrm{~kg} \mathrm{ha}^{-1}$ of $\mathrm{P}_{2} \mathrm{O}_{5}$ and $50 \mathrm{~kg} \mathrm{ha}^{-1}$ of $\mathrm{K}_{2} \mathrm{O}$ ), with sources such as urea, simple superphosphate, and potassium chloride, respectively. Five kilograms ha ${ }^{-1}$ of $\mathrm{K}_{2} \mathrm{O}$ in the form of potassium chloride and $120 \mathrm{~kg} \mathrm{ha}^{-1}$ of $\mathrm{N}$ in the form of urea were applied when the plants showed five fully developed leaves.

When $50 \%$ of the plants were weighed down, 30 plants were collected per parcel in the central third of the leaf at the base of the ear, then the plant material was washed with distilled water, diluted detergent solution, a solution of $\mathrm{HCl} 0,1$ mol L-1 and washed again with distilled water.

Following the plant material was placed to dry in a forced ventilation oven at $65^{\circ} \mathrm{C}$ for 72 hours, the time required for the material to reach constant weight. Subsequently, the plant material was ground in a Willey mill, and the leaf $\mathrm{Zn}$ content was determined following the methodology described by Raij et al. (1996).

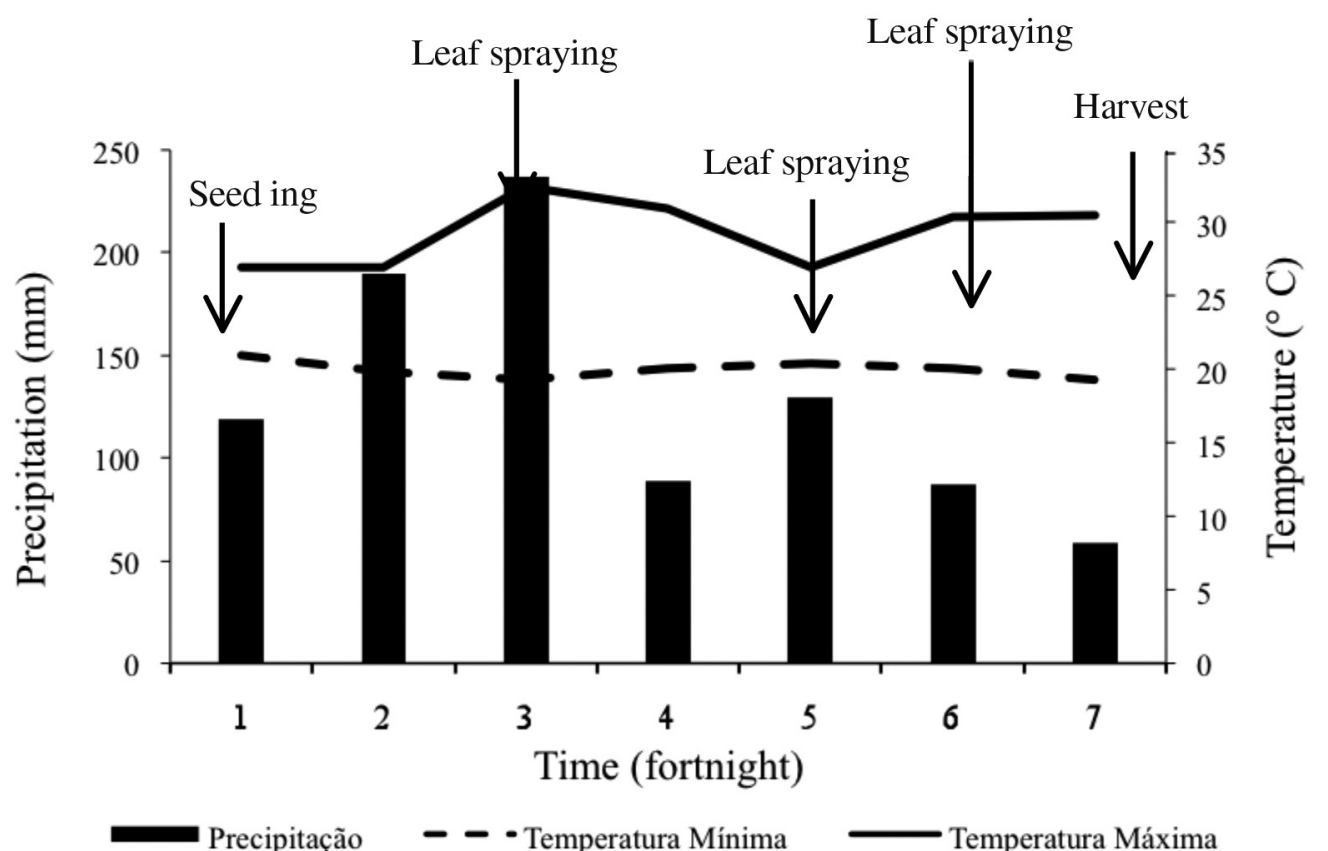

Figure 2. Bi-weekly mean values of maximum and minimum air temperatures and rainfall during the experimental period. Source: FCAV/Unesp Agroclimatological Station, 2016. 1: November 2015; 2 and 3: December 2015; 4 and 5: January 2016; 6 and 7: February 2016; March 8, 2016. 
In the R1 stage of the plants, the leaf area of the plants was evaluated.

The grain yield was evaluated by harvesting the ears of the four central lines of each plot. The ears were then threshed, and the grains heavy. The data were transformed into $\mathrm{Mg}$ ha- 1 and corrected to $13 \%$ moisture (wet basis). The stand was determined in each plot at the time of harvest. Then, in each plot, approximately $200 \mathrm{~g}$ of grains were sampled to analyze the $\mathrm{Zn}$ content.

The data were submitted to analyze of the variance, using the $\mathrm{F}$ test at $5 \%$ of probability. When significant to the sources and $\mathrm{Zn}$ doses were compared by the Tukey test at the 5\% probability level. The Pearson correlation analysis was performed between the production and the leaf content and the $\mathrm{Zn}$ grain. The analyzes were carried out using the statistical program AgroEstat.

\section{Results and discussion}

\section{Experiment I}

The interaction between Mn's sources and doses and the isolated effect of Mn sources did not affect the leaf content of Mn and the dry matter of soybean plants (Table 1). Regarding the

Table 1. Mn leaf content and dry matter yield of soybean plants as a function of applying sources and doses of $\mathrm{Mn}$ via foliar.

\begin{tabular}{lcc}
\hline \multicolumn{1}{c}{ Treatments } & Mn leaf content & Dry matter \\
\hline Sources Mn (S) & $\mathrm{mg} \mathrm{kg}^{-1}$ & g por vaso \\
MnSO $_{4}$ & 85.90 & 2.76 \\
Mn-EDTA & 68.40 & 2.77 \\
Mn-Lignosulfonate & 70.60 & 2.73 \\
Mn-Polyol & 81.80 & 2.74 \\
Test F & $2.12^{\mathrm{NS}}$ & $0.02^{\mathrm{NS}}$ \\
\hline & Doses of $\mathrm{Mn}\left(\mathrm{g} \mathrm{ha}^{-1}\right)(\mathrm{D})$ & \\
\hline 0 & $21.00 \mathrm{~b}$ & $1.98 \mathrm{~b}$ \\
175 & $101.50 \mathrm{a}$ & $3.14 \mathrm{a}$ \\
350 & $104.70 \mathrm{a}$ & $3.12 \mathrm{a}$ \\
Test F & $98.00^{* *}$ & $45.62^{* *}$ \\
\hline Interaction S x D & $0.93^{\mathrm{NS}}$ & $0.22^{\mathrm{NS}}$ \\
\hline CV\% & 21.9 & 12.3 \\
\hline
\end{tabular}

NS not significant; ${ }^{* *}$ significant at $1 \%$ probability by the test $\mathrm{F}$. Means followed by the same letters in the column do not differ from each other, by Tukey test, at $5 \%$ probability. isolated effect of Mn sources, a similar result was obtained by McBeath and McLaughlin (2014), who found no difference in the dry matter yield of wheat plants using soluble salts or chelates. Note that the alternative source of $\mathrm{Mn}$ in the form of complexes with polyols did not stand out from the other sources, possibly since it did not potentiate the mobility of the $\mathrm{Mn}$ in the plant that could increase the residual effect of the foliar fertilization.

Regarding the application of Mn doses, there was an increase in leaf Mn content and the plant's dry matter production, regardless of the source of Mn used (Table 1).

The beneficial effect of foliar application of Mn was possibly due to the low micronutrient content in the soil (Raij et al., 1996), and soybean cultivation was responsive to $\mathrm{Mn}$ application. However, in the present work, transgenic soybean was used, which, because of the added gene, could alter some physiological processes of the plant, delaying the absorption and translocation of $\mathrm{Mn}$, which would require a suplementary addition of this micronutrient, to avoid possible deficiency and Soybean.

It is important to emphasize that the plants that did not receive $\mathrm{Mn}$ foliar application in the control treatment presented Mn deficiency symptoms in the V3 vegetative stage (approximately 18 days after the emergence of the plants), these deficiency symptoms are characterized by internerval chlorosis in the younger leaves, dry matter yield, and lower Mn leaf content in soybean plants compared to micronutrient applications (Table 1).

Mn deficiency in soybean in areas with low soil content occurs in the vegetative stages V3 or in the next stages due to the micronutrient's increased requirement in these phases. This fact naturally induces a decrease in soybean dry matter production widely reported in the literature (Santos et al., 2017).

\section{Experiment II}

There was no interaction between the sources and doses of B on B content in leaf and grains and grain yield (Table 2). However, increasing $\mathrm{B}$ concentrations independently of the source promoted a linearly adjusted increase in leaf B content (Figure 3). The control treatments and the doses of 450 and $900 \mathrm{~g} \mathrm{ha}^{-1}$ of B presented 
Table 2. B content in leaf and grain and grain yield of soybean plants as a function of applying sources and doses of B via leaf.

\begin{tabular}{lccc}
\hline \multirow{2}{*}{ Treatments } & \multicolumn{2}{c}{ Content of B } & \multirow{2}{*}{ Grain production } \\
\cline { 2 - 3 } & Leaf & Grain & \\
\hline Sources B (S) & \multicolumn{2}{c}{$-\mathrm{mg} \mathrm{kg}^{-1}-$} & $\mathrm{Mg} \mathrm{ha}^{-1}$ \\
\hline Boric acid & 50.70 & 4.87 & 3.70 \\
B-Polyol & 50.50 & 4.90 & 3.67 \\
Test F & $0.01^{\mathrm{NS}}$ & $0.10^{\mathrm{NS}}$ & $0.06^{\mathrm{NS}}$ \\
\hline Doses of B $\left(\mathrm{g} \mathrm{ha}^{-1}\right)$ & $(\mathrm{D})$ & & \\
\hline 0 & 35.20 & 4.95 & 3.63 \\
450 & 41.70 & 4.88 & 3.80 \\
900 & 49.70 & 4.98 & 3.65 \\
1.350 & 75.80 & 4.72 & 3.78 \\
Test F & $57.44^{* *}$ & $1.22^{\mathrm{NS}}$ & $0.40^{\mathrm{NS}}$ \\
\hline Interaction S x D & $0.10^{\mathrm{NS}}$ & $1.16^{\mathrm{NS}}$ & $0.50^{\mathrm{NS}}$ \\
\hline $\mathrm{CV}(\%)$ & 11.4 & 5.4 & 7.0 \\
\hline
\end{tabular}

NS not significant; ${ }^{* *}$ significant at $1 \%$ probability by $\mathrm{F}$ test.

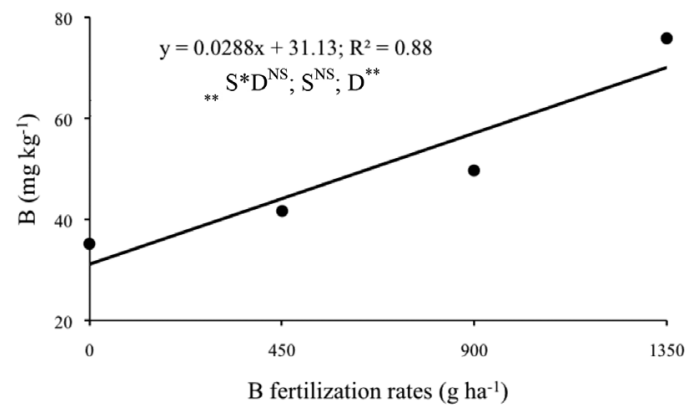

Figure 3. Leaf $\mathrm{B}$ content as a function of the application of foliar B doses in soybean plants. S- sources of B; D- doses of B. NS and ${ }^{* *}$ Not significant and significant at $1 \%$ probability by $\mathrm{F}$ test, respectively.

adequate micronutrient contents according to Raij and Cantarella (1997) (30-50 $\left.\mathrm{g} \mathrm{kg}^{-1}\right)$, while the highest dose of the element induced Leaf content considered to be high.

Although the soil used presents a B content considered low (Raij et al., 1996), the lack of response of the plant to the application of $\mathrm{B}$ doses concerning grain production was possible because the nutritional status of the plants' Control was considered adequate and also by the foliar absorption of B is relatively slow. The foliar spraying was carried out in high rainfall season (Figure 1), which may favor washing the element on the leaf.
It was observed that the of B-polyol and boric acid applications similarly increase leaf content and grains (Table 2). This result may indicate that probably the use of polyol complexed B in the soybean crop did not allow the formation of a mobile sugar-B complex in the plant, possibly due to the low stability of the complex Formed, this occurs when the ratio of polyol to B does not exceed 100: 1.

\section{Experiment III}

It was observed that the doses of $\mathrm{Zn}$ independent of the source were important to increase the $\mathrm{Zn}$ content in leaf, and grains, leaf area and grain yield (Table 3).

The similarity of soluble $\mathrm{Zn}$ sources and chelates in nutrition and maize production was also observed in another grass, the rice that is demanding in the micronutrient as indicated by Shivay et al. (2016).

It should be remarked that the control treatment plants that did not receive $\mathrm{Zn}$ foliar application showed, in the initial stages, about 15 days after plant emergence Zn deficiency symptoms, characterized by white/yellow bands between the main vein and the edges of the leaves.

The beneficial effect of $\mathrm{Zn}$ foliar application on maize production was possible due to the low micronutrient content in the soil (Raij et al. 1996) and the improvement in the nutritional status where the $\mathrm{Zn}$ doses increased the average leaf content $\left(15-50 \mathrm{~g} \mathrm{~kg}^{-1}\right)$ his hypothesis was verified in this study, based on the correlation between grain yield and leaf content $\left(r=0.75^{* *}\right)$.

This increase of the leaf element favored the leaf area, possibly because $\mathrm{Zn}$ acts in the formation of tryptophan, which is a precursor of indole-acetic acid, a growth-promoting phytohormone.

The foliar application of $\mathrm{Zn}$, in addition to the increase in production, increases the grain micronutrient content, possibly occurred due to its absorption and translocation without phloem, as reported in another grass used in the isotopic technique $\left({ }^{65} \mathrm{Zn}\right)$. Thus, $\mathrm{Zn}$ can be re-translocated to other organs such as grains (Boonchuay et al., 2013) that induce increase protein protection during the beginning of seed formation. In this work, we have shown that $\mathrm{Zn}$ is related to protein synthesis because about 2800 proteins need this element for its structure and functional integrity. 
Table 3. Zn content in leaf and grain, leaf area and grain yield of maize plants as a function of applying sources and $\mathrm{Zn}$ doses via leaf.

\begin{tabular}{|c|c|c|c|c|}
\hline \multirow{2}{*}{ Treatments } & \multicolumn{2}{|c|}{ Zn content } & \multirow{2}{*}{ Leaf area } & \multirow[t]{2}{*}{ Grain production } \\
\hline & Leaf & Grain & & \\
\hline Sources Zn (S) & \multicolumn{2}{|c|}{$\mathrm{mg} \mathrm{kg}^{-1}$} & $\mathrm{~m}^{2} \mathrm{~m}^{-2}$ & $\mathrm{Mg} \mathrm{ha}^{-1}$ \\
\hline Zn Sulfate & 20.1 & 37.0 & 4.20 & 7.57 \\
\hline Zn - EDTA & 19.1 & 35.2 & 4.13 & 7.43 \\
\hline Zn - Polyol & 19.8 & 35.2 & 4.13 & 7.70 \\
\hline Test F & $0.15^{\mathrm{NS}}$ & $0.45^{\mathrm{NS}}$ & $0.02^{\mathrm{NS}}$ & $0.59^{\mathrm{NS}}$ \\
\hline \multicolumn{5}{|c|}{ Doses of $\mathrm{Zn}\left(\mathrm{g} \mathrm{L}^{-1}\right)-\mathrm{D}$} \\
\hline 0 & 14.2 & 31.7 & 3.50 & 6.28 \\
\hline 1 & 19.8 & 38.6 & 4.45 & 8.37 \\
\hline 2 & 25.0 & 37.0 & 4.50 & 8.07 \\
\hline Test F & $16.53^{* *}$ & $5.48^{*}$ & $4.25^{*}$ & $41.90^{* *}$ \\
\hline \multicolumn{5}{|c|}{ Interaction F x D } \\
\hline Test F & $0.11^{\mathrm{NS}}$ & $0.44^{\mathrm{NS}}$ & $0.02^{\mathrm{NS}}$ & $0.20^{\mathrm{NS}}$ \\
\hline $\mathrm{CV}(\%)$ & 20.22 & 12.86 & 19.73 & 6.91 \\
\hline
\end{tabular}

Ns not significant; **, * significant at the $1 \%$ and $5 \%$ probability level, by the test F. Means followed by the same letters in the column do not differ from each other by the Tukey test, at $5 \%$ probability.

In this scenario, increased $\mathrm{Zn}$ concentration in corn plant grains, in addition to increasing production, some improvements to human health, in which a $\mathrm{Zn}$ deficiency is observed in several countries of the world, especially for those with access Limited to $\mathrm{Zn}$ in the diet. Thus, biofortification of cereals with Zn, which is a nutritional intervention in these countries.

\section{Conclusion}

The foliar application of soluble sources, chelates and complexed with $\mathrm{Mn}$ and B polyol in the crop, soybeans and $\mathrm{Zn}$ in the corn crop show similar agronomic efficiencies in the nutritional status of the plant and in grain production.

\section{Literature Cited}

Ajiboye, B.; Cakmak, I.; Paterson, D.; De Jonge, M.D.; Howard, D.L.; Stacey, S.P.; McLaughlin, M.J.

2015. X-ray fluorescence microscopy of zinc localization in wheat grains biofortified through foliar zinc applications at different growth stages under field conditions. Plant and Soil, 392: 357-370.

Boonchuay, P.; Cakmak, I.; Rerkasem, B.; e Prom-U-Thai, C. 2013. Effect of different foliar zinc application at different growth stages on seed zinc concentration and its impact on seedling vigor in rice. Soil science and plant nutrition, 59: $180-188$.

Brown, P.H.; Hu H.

1998. Phloem boron mobility in diverse plant species. Botânica Acta, 111: 331-335.

Büll, L.T.

1993. Nutrição mineral do milho. In: Büll, L.T., H. Cantarela. (Ed.). Cultura do milho: fatores que afetam a produtividade. Associação Brasileira para Pesquisa da Potassa e do Fostato.Piracicaba, Brazil. pp. 63-145.

Calonego, J.C.; Ocani, K.; Ocani, M.; Santos, C.H.D.
2011. Adubação boratada foliar na cultura da soja. In Colloquium Agrariae, 6: 20-26.

Camargo, P.N. de.; Silva, O.

1990. Manual de nutrição foliar. Instituto Campineiro de Ensino Agrícola. São Paulo, Brazil. 251 p.

Chatterjee, M.; Tabi, Z.; Galli, M.; Malcomber, S.; Buck, A.; Muszynski, M.; Gallavottia, A.

2014. The Boron efflux transporter rotten ear is required for maize inflorescence development and fertility. The Plant Cell, 26: 2962-2977.

Fernández, V.; Brown, P.

2013. From plant surface to plant metabolism: the uncertain fate of foliar-applied nutrients. Front Plant Sci, 4: 289.

Fernández, V.; Sotiropoulos, T.; Brown, P.

2013. Foliar fertilization. Scientific principles and field practices. International Fertilizer Industry Association. Paris, France. 140 p.

Fernando, D.R.; Lynch, J.P.

2015. Manganese phytotoxicity: new light on an old problem. Ann. Bot., 116: 313e319. 
Fernando, D.R.; Marshall, A.T.; Forster, P.I.; Hoebee, S.E.; Siegele, R.

2013. Multiple metal accumulation within a manganesespecific genus. Am. J. Bot., 100: 690e700.

Gobarah, M.E.; Tawfik, M.M.; Zaghloul, S.M.; Amin, G.A. 2014. Effect of combined application of different micronutrients on productivity and quality of sugar beet plants (Beta vulgaris L.). Int. J. Plant Soil Sci., 3: $589-598$.

Hajiboland, R.; Farhanghi, F.; Aliasgharpour, M.

2012. Morphological and anatomical modifications in leaf, stem and roots of four plant species under boron deficiency conditions. Anales de Biología, 34: 15-29.

Imran, M.; Rehim, A.

2017. Zinc fertilization approaches for agronomic biofortification and estimated human bioavailability of zinc in maize grain. Archives of Agronomy and Soil Science, 63: 106-116.

McBeath, T.M.; McLaughlin, M.J.

2014. Efficacy of zinc oxides as fertilisers. Plant and soil, 374: 843-855.

Naga Sivaiah, K.; Swain, S.; Sandeep Varma, V.; Raju, B. 2013. Effect of foliar application of micronutrients on growth parameters in tomato (Lycopersicon esculentum mill.). Discourse. J. Agric. Food Sci., 1: 146-151.

Nasir, M.; Khan, A.S.; Basra, S.A.; Malik, A.U.

2016. Foliar application of moringa leaf extract, potassium and zinc influence yield and fruit quality of 'Kinnow'mandarin. Scientia Horticulturae, 210: 227-235.

Raij, B. van.; Cantarella, H.

1997. Outras culturas industriais. In: Raij, B. van., Cantarella, H., Quaggio, J.A., Furlani, A.M.C. Recomendações de adubação e calagem para o estado de São Paulo. 2. ed.
Boletim técnico, 100. Instituto Agronômico. Campinas, Brazil. pp. 233-239.

Raij, B. van.; Cantarella, H.; Quaggio, J.A.; Furlani, A.M.C. 1996. Recomendações de adubação e calagem para o estado de São Paulo. Boletim técnico, 100. Instituto Agronômico e Fundação IAC Campinas, Brazil. 285 p.

Santos, E.F.; Santini, J.M.K.; Paixão, A.P.; Júnior, E.F.; Lavres, J.; Campos, M.; dos Reis, A.R.

2017. Physiological highlights of manganese toxicity symptoms in soybean plants: Mn toxicity responses. Plant Physiology and Biochemistry, 113: 6-19.

Shivay, Y.S.; Prasad, R.; Kaur, R.; Pal, M.

2016. Relative efficiency of zinc sulphate and chelated zinc on zinc biofortification of rice grains and zinc use-efficiency in Basmati rice. Proceedings of the National Academy of Sciences, India Section B: Biological Sciences, 86: 973-984. Silva, S.L.O.; de Mello R.M.; da Silva, G.P.; da Silva Júnior, G.B.; Rossi, M.L e González, L.C.

2018. Efeitos da omissão de boro e da fertilização foliar na eficiência nutricional e produção de feijão caupi. HortScience, 53 (11): 1683-1688.

Singh, A.K.; Singh, C.P.; Pratibha, S.L.

2013. Effect of micronutrients and sorbitol on fruit set, yield and quality of mango cv. Dashehari. Progressive Horticulture, 45: 43-48.

Wang, J.; Mao, H.; Zhao, H.; Huang, D.; Wang, Z.

2012. Different increases in maize and wheat grain zinc concentrations caused by soil and foliar applications of zinc in Loess Plateau, China. Field crops research, 135: 89-96.

Will, S.; Eichert, T.; Fernández, V.; Müller, T.; Römheld, V. 2012. Boron foliar fertilization of soybean and lychee: Effects of side of application and formulation adjuvants. Journal of Plant Nutrition and Soil Science, 175: 180-188. 
